http://dx.doi.org/10.15762/ZH.2017.47

MIKOEAJ TOMASZEWSKI

(Uniwersytet Mikołaja Kopernika w Toruniu)

\title{
LINIA SWAROŻYŃSKA RODU CZAPSKICH HERBU LELIWA W CZASACH NOWOŻYTNYCH ${ }^{*}$
}

Słowa kluczowe: Prusy Królewskie, szlachta, sejmiki ziemskie, ziemia lęborsko-bytowska, genealogia

Dotychczasowe badania historyczne dotyczące poszczególnych rodów Prus Królewskich nie wyczerpały pól badawczych nad tą tematyką. Od ponad stu lat pojawiają się publikacje, zarówno książkowe, jak i w postaci artykułów naukowych, dotykające kwestii genealogicznych czy majątkowych poszczególnych rodzin szlacheckich. Nie sposób w tym krótkim szkicu przedstawić nawet częściowego dorobku historiografii polskiej lub niemieckiej na temat stanu uprzywilejowanego w Prusach Królewskich w czasach wczesnonowożytnych. Niemniej jednak należy wspomnieć o pracach przedwojennych dotyczących chociażby Jabłonowskich ${ }^{1}$, Bażyńskich² ${ }^{2}$ zy Czemów³ ${ }^{3}$ Publikacje te do dzisiaj zachowują dużą wartość naukową i często są uwzględniane w badaniach prowadzonych przez współczesnych historyków. W ostatnim czasie pojawiły się opracowania kolejnych rodów pruskich, które niewątpliwie zapisały się w historii Pomorza, Kujaw, Warmii i ziemi chełmińskiej. Przykładowo

* Artykuł powstał w związku z realizacją projektu „Tomasz Czapski herbu Leliwa (17111784). Życie i działalność". Projekt został sfinansowany ze środków Narodowego Centrum Nauki przyznanych na podstawie decyzji nr DEC-2015/19/N/HS3/02471.

${ }^{1}$ Wojciech KęTrzyŃski, O Jabłonowskich herbu Prus III, Przewodnik Naukowy i Literacki, R. 4: 1876, nr 11, s. 979-1000.

${ }^{2}$ Idem, O Bażyńskich, Roczniki Towarzystwa Przyjaciół Nauk Poznańskiego (dalej cyt. RTPNP), t. 10: 1878, s. 113-131.

${ }^{3}$ Robert von Flanss, Die von Zehmen (Czema) in Westpreussen, Zeitschrift des historischen Vereins für den Regierungsbezirk Marienwerder, H. 10: 1884, s. 33-64. 
można wskazać opracowania omawiające genealogię i kariery polityczne rodzin Konopackich ${ }^{4}$, Piwnickich ${ }^{5}$ czy Wybickich ${ }^{6}$.

Szkic ten będzie dotyczył rodu Czapskich herbu Leliwa, dokładniej: jednej z jego linii. Mimo że ród ten należał do najpotężniejszych na obszarze Prus Królewskich, nie doczekał się kompleksowego opracowania. Należy jednak wspomnieć, że takie próby, niezbyt udane, były w przeszłości podejmowane przez Elżbietę Walczak. Autorka niestety popełniła wiele błędów merytorycznych dotyczących samej genealogii rodu. Przykładowo: omyłkowo przedstawiała Antoniego Czapskiego zamiast Pawła Tadeusza. Do owych błędów można dodać brak kwerendy archiwalnej w Bibliotece Czartoryskich w Krakowie, Geheimes Staatsarchiv Preußischer Kulturbesitz w Berlinie-Dahlem i wielu innych instytucjach naukowych ${ }^{7}$. Natomiast w ostatnim czasie pierwsze pokolenia rodu przybliżył Krzysztof Mikulski, który w swoich wstępnych badaniach podważył przede wszystkim wiarygodność herbarzy, które często omyłkowo traktowały poszczególnych przedstawicieli Czapskich ${ }^{8}$. Należy również zaznaczyć wkład, jaki włożył Jerzy Dygdała w uporządkowanie drzewa genealogicznego Czapskich herbu Leliwa. Historyk ten w wielu publikacjach podkreślał rolę, jaką ta pomorska rodzina odgrywała zwłaszcza w czasach saskich ${ }^{9}$. Również biogramy opublikowane w Polskim słowniku biograficznym i Słowniku biograficznym Pomorza Nadwiślańskiego przybliżają nam genealogię rodu, jak i kariery poszczególnych osób. Jednak ze względu na swój charakter wspo-

\footnotetext{
${ }^{4}$ Wiesław NowosaD, Konopaccy herbu Odwaga - dzieje pomorskiej rodziny senatorskiej w XV-XVIII w. Studium genealogiczno-majątkowe, Warszawa 2014.

${ }^{5}$ Bartosz Drzewiecki, Tomasz SŁaWIŃski, Piwniccy herbu Lubicz odmieniony od XVI do XX wieku, Warszawa 2016.

${ }^{6}$ Jacek Kowalkowski, Wybiccy herbu Rogala od XVI do XXw. Studium genealogiczno-majątkowe, Warszawa 2015.

${ }^{7}$ Elżbieta WalCZaK, „Czapscy jako ród magnacki na Pomorzu w XVIII w.”, Gdańsk 1986 (maszynopis pracy doktorskiej). Kilka lat po obronie doktoratu autorka ogólnie opisała dzieje rodu w artykule opublikowanym w „Roczniku Gdańskim”, zob. eadem, Kariera rodu Czapskich w XVI-XVIII w., Rocznik Gdański (dalej cyt. RG), t. 46: 1996, z. 1, s. 65-85.

${ }^{8}$ Krzysztof Mikulski, Najstarsze dzieje Czapskich herbu Leliwa (Ze studiów nad genealogia szlachty pomorskiej), [in:] Między wielka polityką a szlacheckim partykularyzmem. Studia z dziejów nowożytnej polski i Europy ku czci profesora Jacka Staszewskiego, red. Kazimierz WAJDA, Toruń 1993, s. 353-364.

${ }^{9}$ Jerzy DygdaŁa, Krzysztof Mikulski, Zmiany w elicie władzy Prus Królewskich w XVXVIII w. (czynniki awansu, trwania i upadku), [in:] Szlachta i ziemiaństwo na Pomorzu $w$ dobie nowożytnej XVI-XX w. Materiały sympozjum 9 kwietnia 1992 r., red. Jerzy DyGdAŁA, Toruń 1993, s. 7-29; Jerzy DygdaŁA, Sarmata oświecony - życie i poglądy polityczno-pedagogiczne ostatniego wojewody chetmińskiego Franciszka Stanisława Czapskiego, [in:] Oświecenie. Myśl, kultura, red. Julian Platt, Gdańsk 1995, s. 319-342; idem, Podskarbi wielki koronny Jan Ansgary Czapski - budowa pozycji społecznej i prestiżu nowego magnata w pierwszej połowie XVIII w., Zapiski Historyczne (dalej cyt. ZH), t. 70: 2005, z. 1, s. 27-52.
} 
mniane biogramy nie mogą dać syntetycznego ujęcia dziejów tego rodu szlacheckiego $^{10}$. Co więcej, czytelnik nie znajdzie w tego typu publikacjach wielu informacji na temat Czapskich wywodzących się ze Swarożyna. Warto jednak wspomnieć, że o niektórych zagadnieniach dotyczących roli politycznej i majątkowej Czapskich traktują liczne publikacje Wacława Odyńca. Dotyczą one jednak przedstawicieli pozostałych linii rodowych ${ }^{11}$. O tej rodzinie znajdziemy także informacje w osiemnastowiecznych i znacznie późniejszych wspomnieniach, m.in. Marcina Matuszewicza czy Marii Czapskiej ${ }^{12}$.

W pierwszej kolejności, przed zgłębieniem bardziej szczegółowych zagadnień, należałoby się skupić na omówieniu herbu, którym pieczętował się ród Czapskich. Ich herbem była Leliwa, która - jak zauważa Włodzimierz Dworzaczek - występowała niezwykle często na obszarze Pomorza ${ }^{13}$. Notabene Karol Górski w swoich badaniach zaznaczył, że w herbach rycerstwa, a potem szlachty pomorskiej i kaszubskiej pojawiają się motywy gwiazd i półksiężyca ${ }^{14}$. Wspomniany K. Mikulski także zwraca uwagę na to, że (domniemani) protoplaści Czapskich używali pieczęci z wymienionymi motywami ${ }^{15}$. Ten znak herbowy znany był już w średniowieczu, a przykładem służą tutaj zapiski Jana Długosza oraz herbarze: Złotego Runa, Gelrego i Bellenville ${ }^{16}$. Marginalne znaczenie dla powyższych rozważań ma to, że legenda rodowa Czapskich odwołuje się do niemieckiego rycerza Henryka von Hutten, który w 930 r. otrzymał tytuł hrabiowski od cesarza Henryka I. Co ciekawe, owa opowieść została przez innych autorów herbarzy rozwinięta i mówiła o przodku Leliwitów, który w latach $1118-1120$ walczył $z$ Pomorzanami ${ }^{17}$. To właśnie od tej legendarnej postaci miał pochodzić późniejszy przydomek rodziny - von Hutten. Według

${ }^{10}$ Polski słownik biograficzny (dalej cyt. PSB), t. 4, Kraków 1938, s. 177-196: biogramy 26 przedstawicieli tej rodziny (m.in. autorstwa księdza Alfonsa Mańkowskiego); Słownik biograficzny Pomorza Nadwiślańskiego, t. 1, red. Stanisław Gierszewski, Gdańsk 1992, s. 247-261.

${ }^{11}$ Wacław Odyniec, Dzieje Prus Królewskich 1454-1772, Warszawa 1972, passim; idem, Przystąpienie województwa pomorskiego do konfederacji barskiej, ZH, t. 34: 1969, z. 3, s. 147-153.

${ }_{12}$ Maria Czapska, Europa w rodzinie, Paryż 1970; Pamiętniki Marcina Matuszewicza, kasztelana brzesko-kujawskiego 1714-1765, wyd. Adolf PAwIŃski, t. 1-2, Warszawa 1876; Listy Jana Jerzego Przebendowskiego podskarbiego wielkiego koronnego do Jana Szembeka podkanclerzego i kanclerza wielkiego koronnego z lat 1711-1728: „... Jako sobie pościelemy na tym sejmie, tak spać będziemy...”, oprac. Adam PerŁakowski, Kraków 2010; Podróże litewskiego magnata do Gdańska, Człuchowa, a nawet i dalej...: fragmenty „Diariusza” Michała Kazimierza Radziwiłła „Rybeńki” z lat 1721, 1737 i 1752, wyd. Jerzy DygdaŁA, Warszawa 2013.

${ }^{13}$ Włodzimierz DworzaczeK, Leliwici Tarnowscy - z dziejów możnowładztwa małopolskiego. Wiek XIV-XV, Warszawa 1971, s. 45.

${ }^{14}$ Karol Górski, Pomorze w dobie wojny trzynastoletniej, Poznań 1933, s. 299-301.

${ }^{15}$ K. Mikulski, op.cit., s. 355-356.

${ }^{16}$ Szerzej na temat herbu Leliwa zob. Sławomir GóRzyński, Jerzy Kochanowski, Herby szlachty polskiej, Warszawa 1992, s. 91-92.

${ }^{17}$ K. Mikulski, op.cit., s. 354. 
ustaleń Edwarda Brezy przydomek ten wziął się od czapki (z języka niemieckiego der Hut). Natomiast końcówkę -en wykorzystano przez analogię do wielu nazw osobowych formie pluralnej typu Goddentowen, Jarocken itd. Co ciekawe, autor ten podaje interesującą informację odnoszącą się do Jana Karola Dachnowskiego, który nie znał tego przydomku. Sam człon „von Hutten” miał zostać dopisany w późniejszym czasie do rękopisu tego herbarza „obcą ręką”"

Przedmiotem dociekań jest gałąź swarożyńska Czapskich, która niewątpliwie jest o wiele mniej znana niż linia bąkowska czy smętowska. W literaturze marginalnie traktowano gałąź swarożyńską, chociażby ze względu na to, że Czapscy ze Swarożyna m.in. pod względem majątkowym i politycznym odbiegali od pozostałych linii. Także niektóre herbarze nie wspominają o Czapskich ze Swarożyna. Z kolei te opracowania, które mówią o tej gałęzi, poświęcają jej stosunkowo mało miejsca. Seweryn Uruski napisał: „Jan, dziedzic na Swarożynie, którego potomkowie osiedlili na Pomorzu i Kaszubach, i już od połowy XVII w. w większej części zniemczeni nie posiadali znaczenia w Rzeczypospolitej”19. Nie do końca należy się z tymi słowami zgodzić, ponieważ co najmniej jeden Czapski z tej linii dorobił się kilku znacznych urzędów. Niemniej jednak zdecydowana większość przedstawicieli tej linii wskutek wielu okoliczności nie zrobiła błyskotliwych karier ani nie dorobiła się znacznych majątków ziemskich w porównaniu z krewnymi z linii bąkowskiej lub smętowskiej. Oczywiście w tym artykule nie będę w stanie całościowo omówić wszystkich aspektów związanych z tą linią, dlatego ograniczę się do kwestii genealogicznych, tak aby ogólnie scharakteryzować dzieje tej pruskiej rodziny w XVI-XVIII w. Cezury czasowe starałem się zamknąć we wspomnianych stuleciach, jednakże w niektórych przypadkach wykroczę poza te ramy, omawiając chociażby protoplastów rodziny, którzy na obszarze Pomorza aktywnie udzielali się w obszarze polityki, jak i gromadzenia dóbr. W szkicu postaram się także pokrótce przedstawić sprawy majątkowe oraz rozwój karier politycznych poszczególnych członków rodu Czapskich ze Swarożyna.

By zrozumieć, jak doszło do wyodrębnienia się linii swarożyńskiej, należy nieco przybliżyć pierwsze pokolenia Czapskich, nie wdając się w szczegółowe aspekty ich pochodzenia, a także w badania toponomastyczne. W herbarzach poczet rodziny rozpoczyna Marcin, ławnik ziemski świecki, który ożenił się z siostrą Jana i Jerzego Konopackich - Małgorzatą (?). Nie jesteśmy pewni jej imienia, a dodatkową trudność w uporządkowaniu genealogii sprawia m.in. Teodor Żychliński, który w swoim dziele zawarł wiele błędnych informacji odnoszących się do pokrewieństwa poszczególnych członków rodu Czap-

${ }^{18}$ Edward BrezA, Pochodzenie przydomków szlachty pomorskiej, Gdańsk 1986, s. 99-100.

${ }^{19}$ Seweryn URUski, Rodzina. Herbarz szlachty polskiej, t. 1, Poznań 1904, s. 361. 
skich $^{20}$. Ostatnie badania Wiesława Nowosada przybliżają nam postać owej Małgorzaty. Istnieje możliwość, że ta przedstawicielka potężnego rodu Prus Królewskich mogła nie być żoną Marcina I, lecz jego syna Marcina II ${ }^{21}$. Wiemy jednak, że Marcin I żył jeszcze w 1570 r., gdy został odnotowany w źródłach jako właściciel Czapelek („Klein Czapel alias Popussin”) ${ }^{22}$. Z kolei jego potomstwo, bez względu na to, kim była jego żona, było reprezentowane przez Juliusza, Sebastiana, Waleriana i Zofię. Niestety nie możemy podać dokładnych dat narodzin jego synów i córki. Skupimy się za to na Juliuszu, który był jednym z synów Marcina II. Od niego to bowiem pochodziły późniejsze gałęzie Czapskich. W połowie XVI w. Juliusz wszedł w związek małżeński z Heleną Wierzbowską, co pozwoliło mu stać się posiadaczem Bąkowa, a także części Płochocina, połowy jeziora Łęg i Rybitwy w Puszczu. Dzięki swojej działalności udało się mu zgromadzić dość pokaźny majątek, który stawiał go w rzędzie bogatych właścicieli ziemskich regionu. Pod koniec życia mógł pochwalić się posiadaniem nie tylko wspomnianego Bąkowa, lecz także Smętowa, Czapli, Swarożyna czy Białych.

Juliusz zmarł 17 VIII 1595 r., pozostawiając sześciu synów i dwie córki ${ }^{23}$. Najstarszym z jego potomków był Marcin, który w podziale dóbr po ojcu objął Smętowo i Smętówko, a także był dzierżawcą klucza komorskiego, należącego do biskupów włocławskich. Był protoplastą nieco uboższej - smętowskiej linii Czapskich. Drugim synem Juliusza był Sebastian, założyciel najbogatszej bąkowskiej linii. Kolejnym był Jan, który założył interesującą nas gałąź swarożyńską. W jego posiadaniu, oprócz części Smętowa, był także Goszyn i Swarożyn w powiecie tczewskim. Należy nadmienić, że dwie ostatnie wsie otrzymał wraz z ręką dziedziczki zamożnej rodziny Swarożyńskich. Inni synowie Juliusza: Andrzej i Krzysztof opuścili Pomorze i udali się na wschód. Pierwszy z nich osiadł na Rusi, natomiast drugi na Litwie. Szósty i zarazem ostatni syn był postacią, o której wiemy najmniej. Prawdopodobnie był dominikaninem toruńskim znanym pod imieniem Seweryn ${ }^{24}$.

Jan, który założył interesującą nas gałąź rodu, był nie tylko właścicielem Swarożyna w województwie pomorskim (powiat tczewski), lecz także dziedzicem wsi położonych poza granicami Prus ${ }^{25}$. Jan Karol Dachnowski w swoim herbarzu wspomina o Janie: „Trzeci syn Juliuszów, Jan Czapski na Swaroży-

${ }^{20}$ Teodor Żychliński, Złota ksiega szlachty polskiej, t. 11, Poznań 1889, s. 50-51.

${ }^{21}$ W. Nowosad, op.cit., s. 65-66.

${ }^{22}$ Źródła dziejowe, t. 23: Polska XVI wieku pod względem geograficzno-statystycznym, t. 12: Prusy Królewskie, cz. 1, wyd. Ignacy Tadeusz Baranowski, Warszawa 1911, s. 185.

${ }^{23}$ K. Mikulski, op.cit., s. 359.

${ }^{24}$ Ibid., s. 361.

${ }^{25}$ E. WALCZaK, op.cit., s. 72. 
nie miał za sobą pierwej Swarożyńską, z którą wziął Swarożyn, spłodził z nią dwóch synów i trzy córki”26. Potomstwo to miał ze swoją pierwszą żoną, nieznaną z imienia Swarożyńską. Po jej śmierci wstąpił w drugi związek małżeński z Anną von Felden Zakrzewską ze znanej szlacheckiej rodziny, która również miała swoje dobra w Prusach Królewskich ${ }^{27}$. Niestety nie wiadomo, czy miał jakiekolwiek potomstwo z drugiego małżeństwa. Istnieją pewne przekazy mówiące o tym, że miał córkę Małgorzatę zmarłą po $1630 \mathrm{r}^{28}$ Trzy lata przed śmiercią swojej drugiej żony (1628) występował jako strona w sporze z rodziną Krokowskich o dobra po Swarożyńskich ${ }^{29}$. Według T. Żychlińskiego był dzierżawcą Hodyni i Żytowej Woli w starostwie mościckim ${ }^{30}$. Będąc przy sprawach jego majątków, należy nadmienić, że opłacał podatek od swych posiadłości swarożyńskich, który wynosił 1 floren (fl.) i osiem groszy (gr) ${ }^{31}$. Udało mu się również nabyć o wiele większą miejscowość - Goszyn w powiecie tczewskim. Płacił z niej $8 \mathrm{fl}$. i $20 \mathrm{gr}^{32}$. Niestety dokładna data jego śmierci nie jest znana, co powoduje dalsze kłopoty w badaniach nad późniejszymi losami rodu Czapskich. Jeszcze ok. 1629 r. występował wraz z synami jako dziedzic Swarożyna w sporze z rodziną Krokowskich ${ }^{33}$. Więcej informacji mamy na temat jego potomstwa. Przykładem są małżeństwa jego córek. Najstarsza z nich - Barbara, urodzona prawdopodobnie w 1588 r., wyszła za mąż za przedstawiciela rodziny Kawęczyńskich ${ }^{34}$. Z kolei druga córka - Anna, urodzona w 1593 r., wyszła

\footnotetext{
${ }^{26}$ Jan Karol DAchnowski, Herbarz szlachty Prus Królewskich z XVII w., oprac. Zdzisław PenteK, Kórnik 1995, s. 141.

${ }^{27}$ Kwestią problematyczną jest to, że na terenie Prus Królewskich żyło kilka rodzin o nazwisku Zakrzewscy. Być może Anna pochodziła od Zakrzewskich z województwa malborskiego. Wspomina o tym Wiesław Nowosad w: idem, Szlachta województwa malborskiego w świetle badań nad procesami migracyjnymi XV-XVIII w., [in:] Szlachta i ziemiaństwo na pograniczach kulturowych dawnej Rzeczypospolitej od XVI do poczatku XX w., red. Dorota Michaluk, Krzysztof MikUlski, Warszawa 2016, s. 123-124.

${ }^{28} \mathrm{Za}$ tę informację serdecznie dziękuję Panu dr. hab. Wiesławowi Nowosadowi.

${ }^{29}$ Archiwum Państwowe w Gdańsku (dalej cyt. APG), Akta miasta Pucka, sygn. 519/56, s. 216. Prawdopodobnie stroną w konflikcie był Ernest Krokowski (Ernst von Krockow), zob. Franz Schultz, Materialien zu einer Geschichte des Hauses Krockow, Zeitschrift des WestpreuBischen Geschichtsvereins, H. 46: 1903, s. 137-187.

${ }^{30}$ T. ŻyCHLIŃsKi, op.cit., s. 51-52.

${ }^{31}$ Regestr poboru podwoynego dnia 25 juny 1648 w Malborku [...], wyd. Stanisław KęTrzyŃSKI, RTPNP, t. 6, Poznań 1871, s. 8-12.

${ }^{32}$ Ibid.

${ }^{33}$ Kartoteka prof. Krzysztofa Mikulskiego: akta metrykalne (dalej cyt. Dane metrykalne), s. 197. Za udostępnienie materiałów serdecznie dziękuję właścicielowi tych danych. Warto nadmienić, że owa baza została uzupełniona również danymi pochodzącymi z badań autora tego szkicu.

${ }^{34}$ Szczątkowe informacje o tych związkach małżeńskich można znaleźć w herbarzach: Kasper NiesıeCKI, Herbarz polski, t. 3, wyd. Jan Nepomucen Bobrowicz, Lipsk 1839, s. 178; T. ŻyCHLIŃSKI, op.cit., s. 52.
} 
za mąż za Mikołaja Kosa, z którym miała aż 10 dziecii ${ }^{35}$. Co warto zaznaczyć, koligacja z Kosami na przełomie XVI i XVII w. oznaczała związanie się ze znanym i bogatym rodem z Prus Królewskich ${ }^{36}$. Natomiast Katarzyna, najmłodsza z sióstr, była w związku małżeńskim z Jerzym Dembiczem, który zawarła w $1612 \mathrm{r}^{37}$

By opisać kolejne pokolenia Czapskich ze Swarożyna, należy skupić się na męskich potomkach Jana. Jak wspomniano, miał on dwóch synów. Pierwszym był Mikołaj (II), który był jednocześnie najstarszym z potomstwa, drugim natomiast Krzysztof (II). O nich wspominają wszystkie herbarze, ale niestety autorzy tych prac podają zaledwie szczątkowe informacje na temat tych postaci, co stanowi duży problem w badaniach genealogicznych ${ }^{38}$. Niedużą aktywnością cechował się jego najstarszy potomek Mikołaj (II), który urodził się ok. 1585 r. ${ }^{39}$ Ożenił się on z Aleksandrą Bąkowską, z którą miał czworo dzieci: Hieronima, Mikołaja, Mariannę i Aleksandrę ${ }^{40}$. Jan Karol Dachnowski wspomina o nim w następujący sposób: „miał za sobą Bąkowską, podkomorzankę pomorską" ${ }^{41}$. Świadczy to oczywiście o skoligaceniu się z bogatą rodziną szlachecką, co było znacznym osiągnięciem realizowanej polityki rodzinnej. Niestety źródła nie dostarczają nam zbyt wielu informacji na temat jego kariery. Wiemy jedynie, że żył jeszcze w maju 1628 r., a zmarł prawdopodobnie w kwietniu $1629 \mathrm{r}^{42}$ Jego żona długo nie pozostała wdową, ponieważ udało się jej związać z Eremianem vel Remigianem Dembińskim, który pełnił funkcję kasztelana rogozińskiego ${ }^{43}$.

O wiele lepiej powiodło się drugiemu synowi Jana, mianowicie Krzysztofowi (II) (urodzonemu ok. 1590, a zmarłemu po 1662 r.). Poślubił on Małgorza-

${ }^{35}$ Dzieci Anny i Mikołaja Kosa to kolejno: Władysław, Andrzej, Kazimierz, Aleksander, Jan, Jerzy, Helena, Elżbieta, Justyna, Zofia, zob. Das Totenbuch des Prämonstrantenserinnen-Kloster Zuckau bei Danzig, hrsg. v. Max Perblach (Quellen und Darstellungen zur Geschichte Westpreussens, t. 5), Danzig 1906, s. 23.

${ }^{36}$ Rodzina Kosów herbu własnego w drugiej połowie XVI w. zaczęła wzmacniać swoją pozycję i z powodzeniem może być zaliczana do najważniejszych rodzin szlacheckich na omawianym obszarze, o czym świadczą kariery senatorskie jej przedstawicieli; zob. Wiesław NowosAD, Archiwa szlachty Prus Królewskich, Torun 2005, s. 21.

${ }^{37}$ J. K. DACHNOWsKi, op.cit., s. 141.

${ }^{38}$ Adam Boniecki, Herbarz polski, t. 3, Warszawa 1900, s. 276; J. K. DACHNowski, op.cit., s. 141; K. NiesIECKI, op.cit., s. 173; T. ŻYCHLIŃsKI, op.cit., s. 52.

${ }^{39}$ Dane metrykalne, s. 94.

${ }^{40}$ J. K. DACHNOWSKI, op.cit., s. 141.

${ }^{41}$ Ibid.

${ }^{42}$ Dane metrykalne, s. 97.

${ }^{43}$ Włodzimierz Dworzaczex, Dembiński Eremian lub Remigian h. Rawicz, [in:] PSB, t. 5, Kraków 1939-1946, s. 64. Wzmianki o tej postaci poczynił także J. K. DACHNowsKi, op.cit., s. 141 . 
tę Manteuffel, która jako wiano wniosła mu Lubocin i Kamlewo w województwie pomorskim ${ }^{44}$. Była ona wdową po Piotrze Lubockim, który pełnił funkcję sędziego ziemskiego tczewskiego w latach $1608-1620^{45}$. Istnieje prawdopodobieństwo, że była to jego druga żona, ponieważ pierwszą mogła być od $1617 \mathrm{r}$. Barbara Gorazdowska. Niestety materiały źródłowe nie pozwalają na całkowite potwierdzenie tej tezy. Nie można wykluczyć, że Małgorzata była zamężna z innym Krzysztofem Czapskim, który żył mniej więcej w tych samych latach, co omawiany Krzysztof $\mathrm{II}^{46}$. Ponadto był on także właścicielem wsi Barłomino. Wieś ta liczyła 5 włók, z czego pół włóki zajmował sołtys, a na pozostałych osiedlonych było pięciu gburów, zobowiązanych do odrabiania przez cztery dni w tygodniu pańszczyzny sprzężajem i przez dwa dni ręcznie ${ }^{47}$. Krzysztof II prowadził bardzo roztropną politykę majątkową, dzięki czemu jego potomstwo, które notabene było dość liczne, mogło zbudować własne podstawy majątkowe. Wiadomo, że w 1648 r. był w posiadaniu Swarożyna, 1/2 Goszyna, Kłębowa, Tyłowa oraz Lubocimia. Oprócz powiększania dóbr aktywnie zajmował się polityką na arenie regionalnej, zwłaszcza w 1638 r., o czym świadczy chociażby wybranie go jako posła na sejm 22 lutego w tym samym roku ${ }^{48}$. Miał siedmioro dzieci, o których będzie mowa dalej.

Skupmy się na potomstwie Mikołaja, które tworzyło trzecie pokolenie tej linii. Najstarszym jego synem był Hieronim, który urodził się ok. 1615 r. Niestety nie znamy dokładnej daty jego śmierci. Natomiast pewne źródła skłaniają nas do supozycji, że żył on jeszcze w roku $1640^{49}$. Biorąc pod uwagę brak informacji na ten temat w źródłach, możemy się domyślać, że nie zrobił żadnej kariery, ani nie dorobił się majątku lub po prostu zmarł w wieku młodzieńczym. Podobną sytuację można zaobserwować u jego młodszego brata - Mikołaja (IV). Urodził się on około 1617 r. i podobnie jak Hieronim nie zdołał nawiązać do sukcesów swojego ojca lub dziadka. Natomiast Anna, najstarsza z córek, urodziła się ok. 1620 r. ${ }^{50}$ Była żoną Pawła Czarlińskiego, przedstawi-

${ }^{44}$ APG, Akta Miasta Pucka, sygn. 519/55, k. 93; E. WALcZAK, op.cit., s. 72.

${ }^{45}$ Urzędnicy Prus Królewskich XVI-XVIII wieku. Spisy, oprac. Krzysztof Mikulski, Wroclaw 1990, s. 149.

${ }^{46}$ Teki Dworzaczka > Grodzkie i ziemskie $>$ Poznań > Rezygnacje $>$ XVII wiek > Część 1, 4267 (nr 1410) 1617; http://teki.bkpan.poznan.pl/index_regesty.html [dostęp: 23 XI 2017 r.].

${ }^{47}$ Wacław Odyniec, Jan Godlewski, Ziemia pucka. Przeszłość i teraźniejszość, Gdańsk 1974, s. 53.

${ }^{48} \mathrm{O}$ jego aktywności ekonomiczno-politycznej zob. APG, Akta miasta Pucka, sygn. 519/57, s. $1,83 \mathrm{v}, 214-216,365,803$.

${ }^{49}$ „Anna, Aleksandra, Hieronimus et Nicolaus, liberi Nicolai et Aleksandrae Bąkowska, nepotis olim Joannis Czapski avi eorum" (Archiwum Państwowe w Poznaniu, wypisy z ksiąg kcyńskich, sygn. 37, k. 547).

${ }^{50}$ Dane metrykalne, s. 98. 
ciela średniozamożnej szlachty pruskiej ${ }^{51}$. Według herbarza Adama Bonieckiego zmarła w 1660 r. ${ }^{52}$ Najmłodszą córką Mikołaja była Aleksandra, o której wiadomo zdecydowanie najwięcej. Przypuszczalnie urodziła się w 1623 r. Była żoną Baltazara Bystrama, herbu Tarnawa, z którym miała trójkę dzieci: Remigiana Ludwika, Konstancję i Zofię Annę. Aleksandra co prawda nie weszła do rodziny senatorskiej, ale związała się z osobą, która aktywnie działała na polu politycznym w Prusach Królewskich ${ }^{53}$.

Dziećmi Krzysztofa II były: Małgorzata (1625), Piotr II (ok. 1627 r.), Zofia (ok. 1630 r.), Ferdynand (1634), Jan IV (1636), Adelgunda (ok. 1639 r.), Katarzyna (ok. 1643 r.) ${ }^{54}$. Najstarsza córka Krzysztofa II Małgorzata żyła w latach 1625-1684. Pochowana została w krypcie klasztoru franciszkanów w Wejherowie. W lutym 1645 r. wyszła za mąż za Jerzego Wejhera ${ }^{55}$. Był on przedstawicielem uboższej linii znanego rodu z powiatu lęborskiego ${ }^{56}$. Natomiast druga córka - Zofia - żyła o wiele krócej niż Małgorzata, bo ok. 20 lat. Związała się z Janem Kosem w 1650 r. ${ }^{57}$ Natomiast trzecia z córek, Adelgunda, wychodziła za mąż dwukrotnie. Najpierw za Stanisława Poklateckiego, a następnie za Aleksandra Biskupskiego ${ }^{58}$. Ostatnia z córek, Katarzyna, wyszła za Jana Zieleniewskiego w $1664 \mathrm{r}^{59}$ Jak widać, najkorzystniej pod względem prestiżu społecznego wyszła za mąż Zofia, ponieważ Kosowie byli pruskim rodem o znacz-

${ }^{51}$ Rodzina Czarlińskich nigdy nie osiągnęła statusu senatorskiego. Jej przedstawiciele pełnili przeważnie niższe, mniej prestiżowe urzędy w prowincji pruskiej, zob. W. NowosAD, Archiwa szlachty Prus Królewskich, s. 24-25.

${ }^{52}$ A. Boniecki, op.cit., s. 276.

${ }^{53}$ Baltazar Bystram był ławnikiem ziemskim tczewskim w latach 1648-1663, zob. Urzędnicy Prus Królewskich, nr 1233. Co ciekawe, syn Aleksandry i Baltazara, Remigian Ludwik, w późniejszym okresie pełnił ten urząd, by później móc awansować na urząd chorążego chełmińskiego, a następnie na podkomorzego pomorskiego; był również starostą radzyńskim i sobowidzkim, zob. ibid., nr 18, 880, 1245.

${ }^{54}$ K. NiEsIECKI, op.cit., s. 178.

${ }^{55}$ Archiwum Diecezjalne w Pelplinie (dalej cyt. ADPelplin), Żarnowiec, Metricalia 145, k. 224.

${ }^{56}$ Wejherowie, z powiatu lęborskiego, od przełomu XVI i XVII w. należeli do najbardziej wpływowych rodów magnackich Prus Królewskich. Świadczyć o tym mogą ich kariery, które w latach 1605-1657 przyniosły im łącznie siedem krzeseł senatorskich. Zwrócić należy jednak uwagę na to, że karierę robiły rody katolickie, a nie protestanckie, czego przykładem jest jedna z linii Wejherów, zob. J. DygdaŁA, K. Mikulski, op.cit., s. 12.

${ }^{57} 25$ IX 1650 r. (ADPelplin, Żarnowiec, Metricalia 145, k. 230).

${ }^{58}$ Obaj szlachcice nie pochodzili z Prus Królewskich, ale z obszaru Wielkopolski, zob. Teki Dworzaczka > Grodzkie i ziemskie > Konin > 10651 (nr. 63) 1680; http://teki.bkpan.poznan.pl/ index_regesty.html [dostęp: 23 XI 2017 r.].

${ }^{59}$ Zob. Teki Dworzaczka > Grodzkie i ziemskie > Kalisz > Inskrypcje > XVII/XVIII wiek, 9634 (nr. 58) 1664; http://teki.bkpan.poznan.pl/index_regesty.html [dostęp: 23 XI 2017 r.]. 
nym potencjale tak majątkowym, jak i politycznym, co potwierdzają chociażby pełnione przez nich funkcje.

Ze względu na powiększanie się majątku i roli politycznej linii swarożyńskiej wskazane jest skupienie się przede wszystkim na męskim potomstwie Krzysztofa II: Piotrze (II), Ferdynandzie i Janie (IV), którzy próbowali aktywnie działać na terenie Prus Królewskich. Pierwszy z braci, Piotr, został tenutariuszem wsi Barłomino ${ }^{60}$, a w jego włościach znajdowały się również takie miejscowości, jak Lubocin, Kębłowo oraz Tyłowo. Według taryfy podatkowej za pierwszą miejscowość płacił 5 zł i 15 gr., natomiast za drugą 5 zł i 27 gr. ${ }^{61}$ Urodził się ok. 1627 r., zmarł natomiast w roku $1697^{62}$. Oprócz solidnie prowadzonej polityki ekonomicznej udało mu się osiągnąć urząd ławnika ziemskiego puckiego $2 \mathrm{X} 1689 \mathrm{r}^{63}$ Poza tym był posłem z powiatu tczewskiego, a na urząd ten został wybrany 17 X 1667 r. Jednak to nie Piotr zrobił dużą karierę, lecz jego młodszy brat Jan (IV), który urodził się w $1636 \mathrm{r}^{64}$ Warto zaznaczyć, że jego ojcem chrzestnym był podstarości pucki Aleksander Białochowski, a matką chrzestną Emiliana Krokowska. Dotychczasowe badania nie pozwalają określić dokładnej daty jego śmierci. Wiemy natomiast, że aktywny był jeszcze w roku $1695^{65}$. Nie będzie pomyłką stwierdzenie, że prowadził najbardziej efektywne życie polityczne spośród przedstawicieli tej linii Czapskich. Był m.in. wielokrotnie wybierany jako poseł na sejmy z powiatu tczewskiego, a także pełnił funkcje skarbnika ziemi oświęcimskiej ${ }^{66}$ oraz ławnika ziemi tczewskiej ${ }^{67}$. Jest też kolejnym przykładem przedstawiciela rodu Czapskich związanego z Wejherami. Ożenił się z Brygidą Wejher, która w posagu wniosła mu takie miejscowości, jak Tyłów, Kłębocin i Lubocin w powiecie puckim. Wiemy również, że do grona jego majątków zaliczało się także Jabłonowo, które wcześniej należało do wspomnianego rodu Wejherów ${ }^{68}$. Ostatnia z podanych wsi pojawia się w lustracjach Prus Królewskich. Według tego źródła na kilka lat przed przejęciem Lubocina przez Czapskich wieś ta miała być za-

${ }^{60}$ Regestr poboru podwoynego dnia 25 juny 1648 w Malborku [...], s. 195; A. BonIECKI, op.cit., s. 281; Opis królewszczyzn w województwach chełmińskim, pomorskim, malborskim w roku 1664, wyd. Józef PACzkowski (Fontes TNT, 32), Toruń 1938, s. 352.

${ }^{61}$ Dane metrykalne, s. 103-104.

${ }^{62}$ Franz Schultz, Geschichte der Kreise Neustadt und Putzig, Danzig 1907, s. 449.

${ }^{63}$ ADPelplin, Żarnowiec, Metricalia 145, k. 224; Urzędnicy Prus Królewskich, s. 148.

${ }^{64}$ Archiwum Państwowe w Gdańsku (dalej cyt. APG), Akta klasztoru cysterek, później benedyktynek w Żarnowcu (dalej cyt. Cysterki, Żarnowiec), sygn. C. 418, k. 106.

${ }^{65}$ Archiwum Państwowe w Poznaniu (dalej cyt. APPoz), Józef Szaniawski, sygn. 55, k. 115.

${ }^{66}$ Biblioteka Czartoryskich (dalej cyt. BCz.), sygn. 979, k. 203-206v.

${ }^{67}$ Ibid.; Urzędnicy Prus Królewskich, s. 163 (nr 1246).

${ }^{68}$ A. Boniecki, op.cit., s. 281; Słownik geograficzny Królestwa Polskiego i innych krajów słowiańskich, red. Filip Sulimierski, Bronisław CHLebowski, Władysław WALEwski, t. 12, Warszawa 1980, s. 746. 
mieszkana przez zaledwie jednego mieszkańca ${ }^{69}$. Pod koniec życia Jan (IV) toczył zacięte spory o Swarożyn z Adamem Potulickim ${ }^{70}$. Nie wdając się w szczegóły omawianej sytuacji, należy powiedzieć, że Jan sprzedał ostatecznie dobra Potulickiemu za bagatela 14000 zł polskich ${ }^{71}$.

Niestety skąpe informacje mamy o Ferdynandzie, który urodził się w maju $1634 \mathrm{r}^{72}$ Nie znamy dokładnej daty jego śmierci. Przypuszczać można, że zmarł między 1681 a 1684 r. Jego ojcem chrzestnym był Jan Białobłocki ${ }^{73}$. Ferdynand ożenił się z Anną Katarzyną Krokowską, z którą miał dwie córki: Annę Małgorzatę Weronikę oraz Annę Katarzynę. W późniejszym okresie został właścicielem wsi Pietrzykowy w powiecie człuchowskim, którą posiadał do spółki z Franciszkiem Goltzem. W 1669 r. mógł uczestniczyć w obradach sejmowych. Jednakże nie ma bezpośrednich dowodów na odbycie przezeń tego poselstwa. Brak męskiego potomka spowodował wygaśnięcie tej gałęzi rodziny. Jego majątek w części został przejęty przez rodzinę Potulickich, ponieważ pierwsza z córek wyszła za mąż za Adama Wawrzyńca Potulickiego ${ }^{74}$. Druga córka była benedyktynką w Żarnowcu ${ }^{75}$. Sprawa pierwszej córki jest o tyle ciekawa, że do małżeństwa z Potulickim przyczynili się jej kuzyni z linii bąkowskiej (zapewne Aleksander Czapski) ${ }^{76}$.

W celu poznania dalszych dziejów tej linii Czapskich należy się skupić na potomstwie Jana (IV), a właściwie tylko na jednym dziecku - Krzysztofie (IV) Teodorze, ponieważ córka, Konstancja Anna zmarła już w 1764 r., w wieku ośmiu lat ${ }^{77}$. Drugiemu dziecku, Krzysztofowi (IV) Teodorowi udało się rozpocząć aktywną karierę. Urodził się on ok. $1669 \mathrm{r}$. W latach młodości miał okazję uczyć się od ojca oraz swoich pozostałych krewnych sposobów budowania splendoru rodu. Nie ulega wątpliwości, że wziął z nich przykład. Brał udział w często zwoływanych na przełomie 1696 i 1697 r. zjazdach szlacheckich w Prusach Królewskich, na których domagał się obrony prowincji przed skonfederowanymi wojskami polskimi. Został wybrany posłem na sejm konwokacyjny $1696 \mathrm{r}$. z powiatu puckiego i sędzią kapturowym dla wojewódz-

${ }^{69}$ Lustracja województw Prus Królewskich 1765, t. 1: Województwo pomorskie, cz. 3: Powiaty świecki, tucholski i człuchowski, wyd. Jerzy DygdaŁA, Toruń 2005, s. 116.

${ }^{70}$ BCz., sygn. 979, k. 305v-308v.

${ }^{71}$ APPoz, Józef Szaniawski, sygn. 55, k. 117.

${ }^{72}$ Dane metrykalne, s. 102.

${ }^{73}$ APG, Cysterki, Żarnowiec, sygn. C. 418, k. 100; znajdziemy tutaj datę urodzenia Ferdynanda - 30 V 1634 r.; śmierć nastąpiła w pierwszej połowie lat osiemdziesiątych XVII w.; zob. APPoz, Józef Szaniawski, sygn. 87, s. 24; sygn. 55, s. 29, 59.

${ }^{74}$ E. Walczak, op.cit., s. 72; Sławomir Leitgeber, Potuliccy, Londyn 1990, s. 82.

${ }^{75}$ APPoz, Józef Szaniawski, sygn. 55, s. 71.

76 T. ŻYCHLIŃsKI, op.cit., s. 53.

77 Teki Dworzaczka > Metrykalia > Katolickie > Część 2, 8384 (Nowe Miasto); http://teki. bkpan.poznan.pl/index_regesty.html [dostęp: 23 XI 2017 r.]. 
twa pomorskiego. Jeszcze w maju 1697 r. był pod Brodnicą, aktywnie działając w pospolitym ruszeniu ${ }^{78}$. Również w maju tegoż samego roku uczestniczył w Suffragii województw y Ziem Koronnych y Wielkiego Xięstwa Litewskiego zgodnie na najjaśniejszego Augusta II ${ }^{79}$. W swoim życiu miał okazję być dworzaninem królewskim, co niewątpliwie umożliwiło mu zapoznanie się ze środowiskiem politycznym panującej dynastii saskiej. Jego działalność polityczna miała ogromne znaczenie dla regionu, a świadczyć o tym mogą wspomniane udziały w zjazdach szlacheckich, zwoływanych w celu zorganizowania obrony Prus przed wojskami króla Szwecji Karola XII. W 1704 r. był sędzią konfederackim województwa pomorskiego, gdy konfederaci w Sandomierzu poparli politykę Augusta $\mathrm{II}^{80}$. Jeszcze przed wkroczeniem do Prus Królewskich Karola XII Krzysztof Teodor miał posłować do Augusta II w sprawie wyrzucenia menonitów i kwakrów ${ }^{81}$. Był osobą popularną w środowisku szlacheckim i zarazem dość wpływową, czego dowodem jest trzykrotny wybór na posła. Zaszczyty te nie stanowiły zwieńczenia kariery Krzysztofa Teodora, ponieważ udało mu się sięgnąć 15 V 1702 r. po urząd chorążego pomorskiego, a także po podkomorstwo pomorskie 13 XII 1710 r. ${ }^{82} \mathrm{Na}$ tym jednak Krzysztof Teodor nie poprzestał: trzy lata przed śmiercią, czyli w roku 1721 udało mu się awansować na urząd kasztelana gdańskiego. Niestety nie wiadomo, kiedy dokładnie otrzymał ten zaszczytny urząd. Według badań K. Mikulskiego kasztelanem był już w lutym 1721 r. ${ }^{3}$ Nie da się ukryć, że popieranie przez niego oraz innych przedstawicieli Czapskich (przede wszystkim jego krewnych ze Smętowa i Bąkowa) polityki Augusta II zaowocowało dla niego i całego rodu wieloma zaszczytami. Otrzymując ten urząd, potwierdził nie tylko wielkie ambicje rodu Czapskich, lecz także swoją pozycję na obszarze Prus Królewskich. Oprócz pomyślnego rozwoju kariery politycznej skutecznie pomnażał swój majątek. Posiadał Lubocim, Kamlewo i Bielsko ${ }^{84}$. Do jego włości należały także Barłomino, Jabłowo, Bielsk, Lipinki i Sopocin w powiecie tczewskim ${ }^{85}$. Przykład Krzysztofa Teodora potwierdza to, że Czapscy ze Swarożyna wiązali się czę-

${ }^{78}$ Stanisław Achremczyк, Czapski Krzysztof Teodor h. Leliwa, [in:] Słownik biograficzny Pomorza Nadwiślańskiego, t. 1, s. 256.

${ }^{79}$ Volumina legum. Przedruk zbioru praw staraniem XX. Pijarów $w$ Warszawie [...], t. 5, Petersburg 1860, s. 458.

${ }^{80}$ Ibid.

${ }^{81}$ Ibid.

${ }^{82}$ Archiwum Państwowe w Toruniu, Akta miasta Torunia, Kat. II, sygn. VII/42, k. 218; Urzędnicy Prus Królewskich, s. 132.

${ }^{83}$ Urzędnicy Prus Królewskich, s. 92 (nr 420).

${ }^{84}$ Taryfy podatkowe ziem pruskich z 1682 roku, wyd. Stanisław KĘTRzyńsKi (Fontes TNT, 5), Toruń 1901, s. 168; Max Bär, Der Adel und der adlige Grundbesitz in Polnisch-Preussen zur Zeit der preussischen Besitzergreifung, Leipzig 1911, s. 199.

${ }^{85}$ T. ŻYCHLIŃsKI, op.cit., s. 52. 
sto z rodziną Wejherów, o których w omówieniu linii swarożyńskiej kilkukrotnie wspominałem. Czapski ożenił się z Anną Brygidą Wejher, co było oczywiście efektem politycznych konotacji tych dwóch pruskich rodów szlacheckich. Krzysztof Teodor zmarł 8 XI $1724 \mathrm{r}^{86}$, zostawiając po sobie jednego, ale godnego potomka - Jana Jerzego, który tak jak ojciec realizował z powodzeniem sukcesywne wzmacnianie pozycji Czapskich ze Swarożyna na politycznej arenie prowincji pruskiej. Zdaniem Kaspra Niesieckiego: „Cała ta familia jest protestancka, od Krzysztofa Czapskiego kasztelana Gdańskiego, który miał za sobą Wejherównę, z nią spłodziwszy jednego syna, ten przeniósł się do Pomeranji, tam familia liczna godnych obywateli, pod panowaniem Pruskiem żyjących znajduje się"87. Jak udowadnia autor herbarza, Czapscy ze Swarożyna byli protestantami, co tłumaczyłoby ich związki małżeńskie z innymi rodami niekatolickimi, w tym z protestancką linią rodu Wejherów.

Kolejne pokolenie reprezentowane przez Jana Jerzego (III) również radziło sobie całkiem dobrze. Ten potomek Czapskich urodził się w 1700 r., jednak co do daty jego śmierci nie mamy dokładnych informacji ${ }^{88}$. Teodor Żychliński w swoim herbarzu napisał, że zmarł w wieku młodzieńczym, jednak nie należy tych informacji uważać za wiarygodne ${ }^{89}$. Prawdopodobnie dożył sędziwego wieku i zmarł, mając 79 lat $^{90}$. Był kolejnym przedstawicielem tej linii rodu, który wszedł w związek małżeński z przedstawicielką rodziny Wejherów. Dnia 17 VII 1736 r. wziął ślub z Marią Małgorzatą Wejher, wdową po Karolu Fryderyku von Böhm, córką Henryka Krzysztofa ${ }^{91}$. Tak jak jego ojciec, Jan Jerzy (III) cieszył się dużą popularnością wśród szlachty, co umożliwiło mu otrzymanie tytułu marszałka sejmiku lęborsko-bytowskiego. Tę zaszczytną funkcję sprawował w latach 1749-1751 ${ }^{92}$. Niewątpliwie przez większą część życia dbał o powiększanie majątku własnego, chociaż początki miał dość trudne. Powodem tego stanu rzeczy była utrata Lubocina, Tyłowa i Kłębocia w 1725 r. na rzecz Jakuba Dunina ${ }^{93}$. Udało mu się co prawda odzyskać wymienione włości, ale po pewnym czasie wydzierżawił je wojewodzie chełmińskiemu Jakubowi Zygmuntowi Rybińskiemu, a następnie wdowie po Rybińskim - Helenie

${ }^{86}$ Towarzystwo Naukowe w Toruniu, Archivum conventus Novensis, s. 272; Paweł CzAPLEWSKI, Senatorowie świeccy, podskarbowie i starostowie Prus Królewskich 1454-1772 (Roczniki Towarzystwa Naukowego w Toruniu, R. 26/28), Toruń 1921, s. 31.

${ }^{87}$ K. NiesieCKI, op.cit., s. 182.

${ }^{88}$ T. ŻYYCHLIŃsKI, op.cit., s. 53.

${ }^{89}$ Ibid.

${ }^{90}$ Marek DzIĘCIELSKI, Organizacja i funkcjonowanie sąownictwa szlacheckiego w ziemi lęborsko-bytowskiej w XV-XVIII w. Urzędnicy, Gdańsk 2006, s. 227-229.

${ }^{91}$ T. ŻYCHLIŃsKI, op.cit., s. 52.

${ }^{92}$ M. Dzięcielski, op. cit., s. 46.

${ }^{93}$ Teki Dworzaczka > Grodzkie i ziemskie > Kościan > Inskrypcje, 9449 (nr. 316) 1729; http://teki.bkpan.poznan.pl/index_regesty.html [dostęp: 23 XI 2017 r.]. 
z Potockich. Nie był to koniec przekazywania w dzierżawę tych majątków trafiły one później w ręce rodziny Przebendowskich. Najpierw dzierżawił je Józef Przebendowski, chorąży pomorski, syn kasztelana elbląskiego, Jakuba ${ }^{94}$. Następnie trafiły do szambelana pruskiego Jana Nepomucena Przebendowskiego. Czym były spowodowane problemy Jana Jerzego (III) z utrzymaniem dóbr ziemskich? Podobnie jak jego ojciec był luteraninem, chociaż w młodości był wychowywany w duchu katolickim. Gdy stał się zadeklarowanym wyznawcą luteranizmu, ukarano go konfiskatą części dóbr ${ }^{95}$. Jan Jerzy większość życia spędził w dobrach w ziemi lęborsko-bytowskiej. Dzięki swojej gospodarności udało mu się dołączyć do majątku także część Pogorszewa (1739 r.), Rozgorze, Janowice i Janowiczki (1756 r.). Dwie pierwsze miejscowości należały do von Natzmera, ale po jego śmierci zostały przyłączone właśnie do dóbr Czapskiego ${ }^{96}$. W tym miejscu należy zaznaczyć, że Jan Jerzy (III) nie stronił od sporów sądowych. Przykładem tego jest chociażby proces w 1729 r. z Katarzyną Poklatecką, córką Jana Józefa Oskiego, który zakończył się w Trybunale Piotrkowskim ${ }^{97}$. Jednym z jego największych politycznych oponentów był Phillip Otto von Grumbkow (1684-1752), który stracił z inicjatywy Jana Jerzego urząd prezydenta Kamery szczecińskiej, a następnie nadstarosty ${ }^{98}$. Może to świadczyć wyłącznie o mocnej pozycji, jaką zajmował ten szlachcic wśród miejscowej elity politycznej regionu. Intensywny pod względem politycznym był dla Jana Jerzego (III) rok 1741. W tym okresie walczył o urząd marszałka sejmiku lęborsko-bytowskiego z Christophem von Sommitzem, popieranym przez króla Fryderyka II. Niemniej poparcie, którego udzielała mu szlachta, spowodowało, że urząd ten przypadł Czapskiemu ${ }^{99}$. Ponownie w źródłach Czapski pojawia się w 1746 r., gdy urzędnicy akcyzowi skonfiskowali mu wódkę, podobnie jak

${ }^{94}$ Józef Przebendowski w latach czterdziestych i pięćdziesiątych XVIII w. powiększył swój majątek m.in. o wymienione miejscowości, zob. Jerzy DygdaŁA, Przebendowscy - osiemnastowieczni magnaci w Prusach Królewskich, [in:] Najstarsze dzieje Wejherowa (Materiały z sesji naukowej), red. Regina Osowicka, Wejherowo 1988, s. 82.

${ }^{95}$ S. АснRемсzук, Czapski Krzysztof Teodor, s. 256.

${ }^{96}$ Zob. opisy w przypisach dotyczących sprawozdania Philippa Ottona von Grumbkowa z przebiegu sejmiku podatkowego z 18 III 1749 r. w: Źródła do dziejów ziemi lęborsko-bytowskiej 1657-1815. Od statusu lenna polskiego do inkorporacji do Królestwa Pruskiego i integracji $z$ Pomorzem pruskim, t. 2: 1740-1815, cz. 1: 1740-1772/1773, oprac. Zygmunt SzultKa, Warszawa 2011, s. 162.

${ }^{97}$ Teki Dworzaczka > Grodzkie i ziemskie > Kościan > Inskrypcje, 9449 (316) 1729; http:// teki.bkpan.poznan.pl/index_regesty.html [dostęp: 23 XI 2017 r.].

${ }_{98}$ Pismo tajnego radcy, nadprezydenta Pomorza pruskiego Philippa Ottona von Grumbkowa do króla Fryderyka Wilhelma I w sprawie zwołania sejmiku lęborskiego, [in:] Źródła do dziejów ziemi lęborsko-bytowskiej, s. 10.

${ }^{99}$ Protokół z obrad sejmiku, Szczecin 1 V 1741 r., [in:] Źródła do dziejów ziemi lęborsko-bytowskiej, s. 37-40. 
niejakiej pani v. Pirch ${ }^{100}$. Nieco światła na jego stan posiadania rzuca rejestr podatkowy z 1749 r. Według tego dokumentu pod informacją o Janowicach i Janowiczkach (ziemia lęborsko-bytowska) widnieje zapis „h. castellanic Czapski 131/2 besetzten, 6 wüste huben, 6 gertner, 1 mühle", z których płacił 72 fl. i 25 gr. Ten sam Czapski zostaje również wymieniony przy opisie miejscowości Krępowice, której był współwłaścicielem. Tutaj został odnotowany jako „h. Czapski $3 \frac{1}{2}$ vorwerk huben, 2 gertner, $1 / 2$ mühle"101.

Jedynym potomkiem Jana Jerzego był Teodor (II) Henryk, który urodził się ok. 1737 r., a zmarł zaledwie trzy lata po śmierci ojca. Nie da się ukryć, że to pokolenie Czapskich ze Swarożyna, jak i późniejsze odgrywały o wiele mniejszą rolę na arenie politycznej Prus Królewskich. Oczywiście wpływ na to miało wiele czynników, jak chociażby „nieco słabszy” potencjał biologiczny, który uwidocznił się z wyjątkami w ostatnich pokoleniach. Teodor Henryk był bardziej „anonimową” postacią niż chociażby jego ojciec czy dziad. Nie sprawował tak jak jego przodkowie ważnych funkcji politycznych ani nie dzierżawił starostw, z których mógłby czerpać zyski. Ożenił się z Adelgundą Wobeser, jednak nie mamy dowodów na to, że małżeństwo to wpłynęło w jakiś znaczący sposób na powiększenie jego stanu majątkowego. Potwierdza to fakt, że gałąź swarożyńska nie mogła się zbliżyć pod względem znaczenia do swoich krewnych z Bąkowa i Smętowa. Teodor Henryk zgromadził w swoich rękach następujące dobra: Janowice, Janowiczki, Rozgórze, część Pogorszewa; Lubocino, Kębłowo, Tyłowo ${ }^{102}$. Uczestniczył w obradach sejmiku lęborsko-bytowskiego w 1768 r. Był członkiem komisji zajmującej się stacjonowaniem oddziałów von Bellinga w starostwie lęborskim ${ }^{103}$. Trzy lata przed śmiercią na wokandę sejmikową trafiła sprawa zajęcia jego towarów kupionych w Gdańsku. Przyczyną tego miało być nieopłacenie akcyzy do skarbu, co spowodowało zajęcie przez Prusaków towarów przewożonych przez Teodora Henryka ${ }^{104}$.

Pozostawił po sobie następujące potomstwo: Marcina Augusta, Małgorzatę Luizę, Henriettę Fryderykę, Wilhelminę i Henryka Aleksandra. Jeśli chodzi o córki, niestety nie możemy powiedzieć o nich nic więcej. Trudno nawet ustalić ich dokładne daty urodzin. Nieco więcej wiemy o synach Teodora Henry-

${ }^{100}$ Protokół z przesłuchania świadków z 15 III 1746 r., [in:] Źródła do dziejów ziemi lęborsko-bytowskiej, s. 119-123.

${ }^{101}$ Rejestr podatkowy szlachty lęborskiej oraz miast Lęborska i Łeby, [in:] Źródła do dziejów ziemi lęborsko-bytowskiej, s. 167.

102 M. DzięCIELsKi, op.cit., s. 227-229.

${ }^{103}$ Uchwała komisji doraźnej sejmiku lęborsko-bytowskiego w sprawie stacjonujących w starostwie dwóch eskadronów husarów regimentu von Bellinga, Lębork, 30 IX 1768 r., [in:] Źródła do dziejów ziemi lęborsko-bytowskiej, s. 298.

${ }^{104}$ Protokół z posiedzenia sejmiku, Lębork, 22 X 1772 r., [in:] Źródła do dziejów ziemi lęborsko-bytowskiej, s. 347-348. 
ka. Pierwszy - Marcin (V) August był współwłaścicielem Janowic, Janowiczek, Rozgórza, 1/5 Krępkowic, 1/4 Unieszynka, części Pogorszewa w 1784 r. Nie znamy jednak dat jego urodzenia i śmierci. Zgon Marcina (V) Augusta nastąpił z pewnością po roku $1784^{105}$. Henryk Aleksander Ferdynand był właścicielem Janowic, Janowiczek, Rozgórza, 1/5 Krępkowic, 1/4 Unieszynka, części Pogorszewa; jako Ferdinand Eugen występował jako właściciel Niedamowa w powiecie kościerskim w latach $1798-1802^{106}$. Ciekawostką jest fakt, że posiadane przez niego dobra przeszły w ręce rodziny von der Osten. Podobnie jak w przypadku jego brata nie znamy jego daty urodzin i śmierci. Utrudnia to badanie dalszych pokoleń rodziny ${ }^{107}$.

Jak zostało zaznaczone wcześniej, Czapscy ze Swarożyna często wiązali się z przedstawicielami rodziny Wejherów, zwłaszcza z jej linią protestancką. Nie było to oczywiście przypadkowe, ponieważ ta ostatnia rodzina na przełomie XVI i XVII w. osiągnęła znaczącą pozycję nie tylko w Prusach Królewskich ${ }^{108}$. $\mathrm{Z}$ drugiej jednak strony Czapscy z tej linii, podobnie jak ich kuzyni, wydawali córki za przedstawicieli uboższej (ale nie ubogiej) szlachty. Dla synów próbowali w miarę możliwości dobierać żony o zbliżonej pozycji majątkowej. Zapewniało to oczywiście pozostanie przez dłuższy czas w kręgu wpływowych rodzin pruskich ${ }^{109}$. Na pewno na pozycji poszczególnych członków tej linii zaważyło to, że byli protestantami. Być może był to nawet główny powód zaistniałej sytuacji.

Analiza przedstawionych tutaj danych i informacji pozwala stwierdzić, że kariera Czapskich ze Swarożyna przebiegała w miarę równomiernie. Oczywiście w porównaniu do spokrewnionej z nimi linii bąkowskiej i smętowskiej ich pozycja nie była tak mocna w Prusach Królewskich, o czym świadczy liczba osiągniętych krzeseł senatorskich. W latach 1697-1772 linia bąkowska miała siedmiu kasztelanów, trzech wojewodów i jednego biskupa. Smętowska natomiast jednego wojewodę i jednego biskupa ${ }^{110}$. Duże zróżnicowanie można dostrzec w zewnętrznych oznakach prestiżu, np. w fundacjach. Był to efekt kilku czynników. Po pierwsze, prowadzenie polityki przez przedstawicieli z linii smętowskiej i bąkowskiej spowodowało stabilne trwanie w kręgach najbogatszych. Po drugie, Czapscy ze Swarożyna nie zrobili spektakularnych karier wojskowych $w$ przeciwieństwie do swoich kuzynów ${ }^{111}$. Nie można ich z całą

${ }^{105}$ Ibid.; M. BÄR, op.cit., nr 1499.

${ }^{106}$ M. B̈̈r, op.cit., nr 1190, 1499.

${ }^{107}$ Ibid., nr 1190.

108 J. DygdaŁA, K. Mikulski, op.cit., s. 12.

${ }^{109}$ Ibid., s. 26.

${ }^{110}$ Jerzy DygdaŁA, Uwagi o magnaterii Prus Królewskich $w$ XVIII stuleciu, ZH, t. 44: 1979, z. 3, s. 66-69.

${ }^{111}$ Wielu Czapskich w XVII w. brało aktywny udział w licznych kampaniach wojennych. 
pewnością zaliczyć do magnaterii, ponieważ w drugiej połowie XVIII w. do tej grupy posiadaczy ziemskich należało w Prusach pięć rodzin: Przebendowscy, Grabowscy, Skórzewscy i dwie linie Czapskich (smętowska i bąkowska) ${ }^{112}$. Mimo koligacji z innymi rodzinami, nawet z tymi znaczącymi (Wejherowie, Czapscy z innych linii), nie udało się im rozwinąć karier senatorskich, w przeciwieństwie chociażby do wielokrotnie wspominanych Czapskich z linii bąkowskiej (Piotr Jan, Jan Ansgary i wielu innych). Tym karierom dużo miejsca poświęcili w swoich pracach m.in. Teresa Zielińska i Jerzy Dygdała ${ }^{113}$. Można pokusić się o stwierdzenie, że jedną z ważniejszych przeszkód uniemożliwiającą swarożyńskiej linii Czapskich awans do grupy zamożnych był, jak się wydaje, brak odpowiedniego zaplecza materialnego, a także wyznanie ewangelickie. Zaliczyć ich można co najwyżej do średniozamożnej szlachty. Żaden z przedstawicieli tej linii nie skoncentrował w swych rękach dóbr większych niż kilka wsi. Tymczasem prowadzenie skutecznej działalności politycznej na większą skalę wymagało poważniejszych nakładów finansowych.

W powyższym artykule nie zaprezentowano całej wiedzy o gałęzi swarożyńskiej. Zasługuje ona niewątpliwie na gruntowną monografię, która pozwoliłaby na pełną analizę funkcjonowania biedniejszej i średniozamożnej rodziny szlacheckiej w prowincji pruskiej. Na przykładzie przytoczonych informacji starano się jedynie wykazać konieczność podjęcia dalszych badań źródłowych nad genealogią szlachty XVI-XVIII w. jako niezbędnego weryfikatora, uznawanych za wiarygodne, polskich herbarzy szlacheckich. Istnieje niewątpliwie potrzeba dalszych badań nad genealogią, by zrozumieć drogę awansu i upadku znaczenia szlachty w Prusach Królewskich.

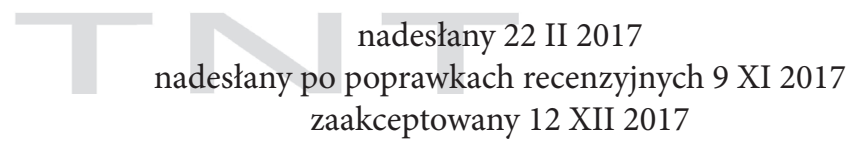

Mgr Mikołaj Tomaszewski

Instytut Historii i Archiwistyki

Uniwersytet Mikołaja Kopernika w Toruniu

e-mail:mik.tomaszewski@wp.pl

Czapscy pojawiają się m.in. na polach Beresteczka w $1651 \mathrm{r}$. czy w wojnie polsko-szwedzkiej 1655-1660, zob. Ludwik Kubala, Wojna szwedzka w roku 1655 i 1656, Lwów 1913, s. 327. Również w wieku XVIII kilku z nich znalazło się na wysokich szczeblach hierarchii wojskowej, np. Paweł Tadeusz Czapski, który doszedł do stopnia generała majora, zob. Jerzy DYgDAŁA, Czapski Paweł Tadeusz h. Leliwa, [in:] Słownik biograficzny Pomorza Nadwiślańskiego, t. 1, s. 257-258.

112 J. DygdaŁA, Uwagi o magnaterii, s. 70.

${ }^{113}$ Teresa Zielińsкa, Magnateria polska epoki saskiej. Funkcje urzędów i królewszczyzn w procesie przeobrażeń warstwy społecznej, Wrocław-Warszawa-Kraków-Gdańsk 1977, s. 235; J. DygdaŁA, Uwagi o magnaterii, s. 75-76; idem, Na marginesie badań nad magnateria polska epoki saskiej, RG, t. 40: 1980, z. 1, s. 187-198. 
The Swarożyn Line of The Czapski Family

of the Coat of Arms of Leliwa in the Early Modern Times

\section{Summary}

Key words: Royal Prussia, noblemen [szlachta], dietines, Lębork-Bytów Land, genealogy

The article addresses the subject matter of the Czapski family of the coat of arms of Leliwa - in particular one of its lines, whose name comes from the name of the village Swarożyn in Royal Prussia. Unlike their relatives from Smętów and Bąków, representatives of the Swarożyn line did not make any spectacular political careers. The outline presents the correct genealogy of the family, which in historiography was often shown erroneously. It should be underlined that no complex study of this family has ever been made despite the fact that the family was quite significant in the $18^{\text {th }}$ century. The Swarożyn line of the family remained in the shadow owing to its Protestant denomination and weaker biological potential. Still, despite problems, several representatives of the Swarożyn line of the Czapski family reached a high social status in the Prussian province.

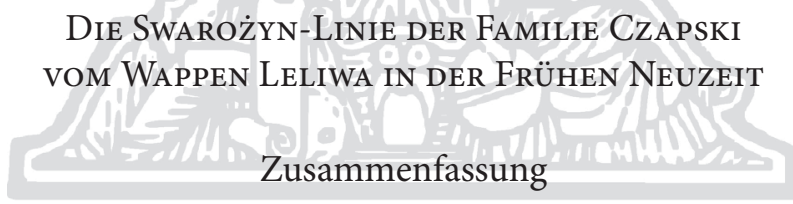

Schlüsselwörter: Königliches Preußen, Adel, Sejmik, Land Lauenburg und Bütow, Genealogie

Der Beitrag behandelt die Thematik des Geschlechtes Czapski vom Wappen Leliwa und genauer einer der Linien, die ihren Namen der Ortschaft Swarożyn (dt. Swaroschin) im Königlichen Preußen verdankt. Im Gegensatz zu ihren Verwandten aus Lauenburg und Bütow machten die Vertreter der Linie Swarożyński keine großen politischen Karrieren. Der vorliegende Abriss präsentiert eine geordnete Genealogie dieses Geschlechtes, welche in der Geschichtsschreibung oft fehlerhaft geschildert wird. Erwähnenswert ist dabei, dass dieses Geschlecht - trotz seiner großen Bedeutung im 18. Jh. - wissenschaftlich nie ausführlich behandelt wurde. Die Linie Swarożyński blieb jedoch im Hintergrund, u. a. wegen der protestantischen Konfession sowie ihres schwächeren biologischen Potenzials. Trotz Hindernisse erreichten einige Vertreter der Linie Swarożyński des Geschlechtes Czapski einen hohen gesellschaftlichen Status in Preussen königlichen Anteils. 
BiBLIOGRAFIA

Achremczyk, Stanisław. “Czapski Krzysztof Teodor h. Leliwa.” In Słownik Biograficzny Pomorza Nadwiślańskiego, t. 1: A-F, ed. S. Gierszewski, 256. Gdańsk: Wydawnictwo Gdańskie, 1992.

Bär, Max. Der Adel und der adlige Grundbesitz in Polnisch-Preussen zur Zeit der preussischen Besitzegreifung. Leipzig: S. Hirzel, 1911.

Boniecki, Adam. Herbarz polski, t. 3. Warszawa: skł. gł. Gebethner i Wolff, 1900.

Breza, Edward. Pochodzenie przydomków szlachty pomorskiej. Gdańsk: UG, 1986.

Czaplewski, Paweł. Senatorowie świeccy, podskarbowie i starostowie Prus Królewskich 1454-1772. Toruń: TNT, 1921.

Czapska, Maria. Europa w rodzinie. Paryż: Res Publica, 1970.

Dachnowski, Jan Karol. Herbarz szlachty Prus Królewskich z XVII w., oprac. Z. Pentek. Kórnik: Biblioteka Kórnicka PAN, 1995.

Das Totenbuch des Prämonstrantenserinnen-Kloster Zuckau bei Danzig, ed. M. Perlbach, "Quellen und Darstellungen zur Geschichte Westpreussens", t. 5. Danzig, 1906.

Drzewiecki, Bartosz, Sławiński, Tomasz. Piwniccy herbu Lubicz odmieniony od XVI do XX wieku. Warszawa: DiG, 2016.

Dworzaczek, Włodzimierz. "Dembiński Eremian lub Remigian h. Rawicz." In Polski Słownik Biograficzny, t. 5, 64. Kraków: Zakład Narodowy im. Ossolińskich, 1939-1946.

Dworzaczek, Włodzimierz. Leliwici Tarnowscy - z dziejów możnowładztwa małopolskiego. Wiek XIV-XV. Warszawa: PAX, 1971.

Dygdała, Jerzy, Mikulski, Krzysztof. “Zmiany w elicie władzy Prus Królewskich w XV-XVIII w. (czynniki awansu, trwania i upadku)." In Szlachta i ziemiaństwo na Pomorzu w dobie nowożytnej XVI-XXw. Materialy sympozjum 9 kwietnia 1992 r., ed. J. Dygdała, 7-29. Toruń: TNT, 1993.

Dygdała, Jerzy. "Czapski Paweł Tadeusz h. Leliwa." In Słownik Biograficzny Pomorza Nadwiślańskiego, t. 1: A-F, ed. S. Gierszewski, 257-258. Gdańsk: Wydawnictwo Gdańskie, 1992.

Dygdała, Jerzy. “Na marginesie badań nad magnaterią polską epoki saskiej.” Rocznik Gdański 40/1 (1980): 187-198.

Dygdała, Jerzy. "Przebendowscy - osiemnastowieczni magnaci w Prusach Królewskich." In Najstarsze dzieje Wejherowa, ed. R. Osowicka, Wejherowo: Muzeum Piśmiennictwa i Muzyki Kaszubsko-Pomorskiej, Towarzystwo Przyjaciół Ziemi Wejherowskiej, 1988.

Dygdała, Jerzy. "Sarmata oświecony - życie i poglądy polityczno-pedagogiczne ostatniego wojewody chełmińskiego Franciszka Stanisława Czapskiego.” In Oświecenie - Myśl - Kultura, ed. J. Platt, 319-342. Gdańsk: UG, 1995.

Dygdała, Jerzy. “Uwagi o magnaterii Prus Królewskich w XVIII stuleciu.” Zapiski Historyczne 44/3 (1979): 57-91.

Dygdała, Jerzy. "Podskarbi wielki koronny Jan Ansgary Czapski - budowa pozycji społecznej i prestiżu nowego magnata w pierwszej połowie XVIII w." Zapiski Historyczne 70/1 (2005): 27-52. 
Dzięcielski, Marek. Organizacja i funkcjonowanie sądownictwa szlacheckiego w ziemi lęborsko-bytowskiej w XV-XVIII w. Urzędnicy. Gdańsk: Wydawnictwo Uniwersytetu Gdańskiego, 2006.

Flanss, Reinhard. "Die von Zehmen (Czema) in Westpreussen." Zeitschrift des Historischen Vereins für den Regierungsbezirk Marienwerder 10 (1884): 33-64.

Górski, Karol. Pomorze $w$ dobie wojny trzynastoletniej. Poznań: Poznańskie Towarzystwo Przyjaciół Nauk, 1933.

Górzyński, Sławomir, Kochanowski, Jerzy. Herby szlachty polskiej. Warszawa: Alfa, 1992.

Kętrzyński, Wojciech. “O Bażyńskich.” Roczniki Towarzystwa Przyjaciół Nauk Poznańskiego 10 (1878): 113-131.

Kętrzyński, Wojciech. “O Jabłonowskich herbu Prus III.” Przewodnik Naukowy i Literacki 11 (1876): 9179-1000.

Kowalkowski, Jacek. Wybiccy herbu Rogala od XVI do XX w. Studium genealogicznomajątkowe. Warszawa: DiG, 2015.

Kubala, Ludwik. Wojna szwedzka w roku 1655 i 1656. Lwów: H. Altenberg, G. Seyfarth, E. Wende i Sp., 1913.

Leitgeber Sławomir. Potuliccy. Londyn: Polska Fundacja Kulturalna,1990.

Lustracja województw Prus Królewskich 1765, t. 1: województwo pomorskie, cz. 3: powiaty świecki, tucholski i człuchowski, wyd. J. Dygdała. Toruń: TNT, 2005.

Mikulski, Krzysztof. "Najstarsze dzieje Czapskich herbu Leliwa (Ze studiów nad genealogią szlachty pomorskiej)." In Między wielką polityka a szlacheckim partykularyzmem. Studia z dziejów nowożytnej polski i Europy ku czci profesora Jacka Staszewskiego, 353-364. Toruń: Wydawnictwo UMK, 1993.

Najstarsze dzieje Wejherowa (Materiały z sesji naukowej), ed. R. Osowicka. Wejherowo: Muzeum Piśmiennictwa i Muzyki Kaszubsko-Pomorskiej, Towarzystwo Przyjaciół Ziemi Wejherowskiej, 1988: 75-91.

Niesiecki, Kasper. Herbarz polski, t. 3, wyd. J. N. Bobrowicz. Lipsk: nakł. i dr. Breitkopfa i Haertela, 1839.

Nowosad, Wiesław. "Szlachta województwa malborskiego w świetle badań nad procesami migracyjnymi XV-XVIII w.” In Szlachta i ziemiaństwo na pograniczach kulturowych dawnej Rzeczypospolitej od XVI do poczatku XXw., eds. D. Michaluk. K. Mikulski, 109-128. Warszawa: DiG, 2016.

Nowosad, Wiesław. Archiwa szlachty Prus Królewskich, Toruń: Wydawnictwo Adam Marszałek, 2005.

Nowosad, Wiesław. Konopaccy herbu Odwaga - dzieje pomorskiej rodziny senatorskiej w XV-XVIII w. Studium genealogiczno-majątkowe. Warszawa: DIG, 2014.

Odyniec, Wacław, Godlewski, Jerzy. Ziemia pucka. Przeszłość i teraźniejszość, Gdańsk: Wydawnictwo Morskie, 1974.

Odyniec, Wacław. "Przystąpienie województwa pomorskiego do konfederacji barskiej." Zapiski Historyczne 34/3 (1969): 147-153.

Odyniec, Wacław. Dzieje Prus Królewskich 1454-1772. Warszawa: PWN, 1972.

Opis królewszczyzn w woj. chetmińskim, pomorskim i malborskim w 1664, wyd. J. Paczkowski, “Fontes 32”. Toruń: TNT, 1938. 
[669] Linia swarożyńska rodu Czapskich herbu Leliwa w czasach nowożytnych

Pamiętniki Marcina Matuszewicza kasztelana brzesko-kujawskiego 1714-1764, wyd. J. Piwiński, t. 4. Warszawa: PiW, 1986.

Polski Słownik Biograficzny, t. 4. Kraków: PAU, 1938.

Regestr poboru podwoynego dnia 25 juny 1648 w Malborku..., ed. S. Kętrzyński. Roczniki Towarzystwa Przyjaciół Nauk Poznańskiego 6 (1871).

Schultz, Franz. "Materialien zu einer Geschichte des Hauses Krockow." Zeitschrift des Westpreusseschen Geschichtsvereins 46 (1903): 137-187.

Schultz, Franz. Geschichte der Kreise Neustadt und Putzig. Danzig: Druck der Danziger Allgemeinen Zeitung, 1907.

Słownik geograficzny Królestwa Polskiego i innych krajów słowiańskich, eds. F. Sulimierski, B. Chlebowski, W. Walewski, t. 12. Warszawa: Wydawnictwo Artystyczne i Filmowe, 1980.

Taryfy podatkowe ziem pruskich z 1682 roku, ed. S. Kętrzyński, “Fontes”. Toruń: TNT, 1901.

Teki Dworzaczka (online: http://teki.bkpan.poznan.pl).

Urzędnicy Prus Królewskich w XVI-XVIII w. Spisy, oprac. K. Mikulski. Wrocław-Warszawa-Kraków: PAN, 1990.

Volumina Legum, przedruk zbioru praw staraniem XX. Pijarów w Warszawie, t. 4-5, oprac. J. Ohryzko. Petersburg: nakł. i druk Jozafat Ohryzko, 1859.

Walczak Elżbieta, "Kariera rodu Czapskich w XVI-XVIII w." Rocznik Gdański 46/1 (1996): 65-85.

Walczak, Elżbieta. Czapscy jako ród magnacki na Pomorzu w XVIII w., Gdańsk 1986 [non printed, UMK Library].

Zielińska, Teresa. Magnateria polska epoki saskiej. Funkcje urzędów i królewszczyzn w procesie przeobrażeń warstwy społecznej. Wrocław: Zakład Narodowy im. Ossolińskich, 1977.

Źródła do dziejów Ziemi Lęborsko-Bytowskiej 1657-1815. Od statusu lenna polskiego do inkorporacji do królestwa pruskiego i integracji z Pomorzem pruskim, t. 2: 1740-1815, cz. 1: 1740-1772/1773, oprac. Z. Szultka. Warszawa: Naczelna Dyrekcja Archiwów Państwowych, 2011.

Żychliński, Teodor. Złota księga szlachty polskiej, t. 11. Poznań: nakł. Jarosława Leitgebera, 1889. 